\title{
PALEO
}

Revue d'archéologie préhistorique

19 | 2007

Spécial table ronde ( 1 ère partie) : Le Gravettien : entités régionales d'une paléoculture européenne, Les Eyzies, juillet 2004

\section{Looking out for the Gravettian in Greece}

Une approche du Gravettien en Grèce.

\section{Eugenia Adam}

\section{(2) OpenEdition}

\section{Journals}

Electronic version

URL: https://journals.openedition.org/paleo/579

DOI: $10.4000 /$ paleo.579

ISSN: 2101-0420

\section{Publisher}

SAMRA

Printed version

Date of publication: 30 December 2007

Number of pages: $145-158$

ISSN: $1145-3370$

\section{Electronic reference}

Eugenia Adam, "Looking out for the Gravettian in Greece", PALEO [Online], 19 | 2007, Online since 23 April 2009, connection on 25 June 2021. URL: http://journals.openedition.org/paleo/579 ; DOI: https:// doi.org/10.4000/paleo.579

\section{(c)}

PALEO est mis à disposition selon les termes de la licence Creative Commons Attribution - Pas d'Utilisation Commerciale - Pas de Modification 4.0 International. 


\title{
LOOKING OUT FOR THE GRAVETTIAN IN GREECE
}

\author{
Eugenia ADAM $^{(1)}$
}

\begin{abstract}
The number of sites and the chronostratigraphic record of the Upper Palaeolithic in Greece does not encourage major overviews. Still, aspects of regional differentiation and temporal variation in the exploitation of resources can be addressed - if only in a preliminary manner - through the currently available data. The region of northwestemGreece offers an opportunity to investigate the character of Gravettian cultural data in this part of the Balkan peninsula. Intensification of research will no doubt enrich the corpus of data and support wider intra- and inter-regional comparisons.
\end{abstract}

Key-Words: Balkans, Kastritsa, Grava, stone industries, organic artefacts, symbolic gear.

Résumé : Une approche du Gravettien en Grèce. Le nombre de sites et les données chrono-stratigraphiques relatifs au Paléolithique supérieur en Grèce n'encourage pas de vastes synthèses. Cependant, quelques particularités régionales et une variation diachronique dans l'exploitation des ressources peuvent être présentées -d'une façon très préliminaire- à partir des données actuellement disponibles. Le nord-ouest de la Grèce offre une opportunité d'analyser les particularités de la culture gravettienne dans cette partie de la péninsule balkanique. II n'est pas douteux que le développement des recherches enrichira cette base documentaire et permettra de plus larges comparaisons intra et inter-régionales.

Mots-clés : Balkans, Kastritsa, Grava, industries lithiques, outillages osseux, éléments symboliques.

\section{BACKGROUND INFORMATION}

Greece is an area of marked climatic and topographic contrasts, with a large Pleistocene and Early Holocene research potential but with a restricted and erratic research history. With the exception of few individual projects in the decades leading to the 1960's, research was practically nonexistent. The 1960's, a decade that could be considered as the golden era of Stone Age research in Greece, resulted in the formation of a corpus of open-air and rockshelter sites representing human activity during the Palaeolithic and secondly the Mesolithic. The First International Congress on the Palaeolithic of Greece and Adjacent areas in 1994 recorded and evaluated the state of research at the time (Bailey et al. 1999). Several projects, initiated since, have brought to light new sequences and sites with occupational evidence from the Paleolithic to the Mesolithic times.

Nevertheless, the record remains patchy. Many factors may be responsible, either individually or in combination, for this: climatic and environmental fluctuations leading to discontinuity of occupation, tectonic and depositional activity affecting the visibility of sites, emphasis on different environmental niches at different times during the Pleistocene, low population densities during part(s) of the Pleistocene, to mention but a few.
The period during which the Gravettian - a "culture" characterized by a remarkable unity in technology, resource exploitation, site use and symbolic and artistic expression (Gamble 1999 ; Otte 1981; Valoch 1996) - flourished in Europe is by common consent taken to fall between 30 and 20 kyr. Few sites in Greece provide sequences corresponding to that period (see tabl. 1); three of these are located in northwestem Greece (Asprochaliko, Kastritsa, Grava), one in Thessaly (Theopetra) and one in the Peloponnese (Franchthi) (fig. 1). No other sites (except possibly for Kephalari in central Greece, which remains regretfully not fully published) can be included in the time and type range of the present paper.

\section{PRESENTATION AND DISCUSSION OF THE DATA}

\section{1 - Thessaly}

Theopetra cave lies in a limestone formation (fig. 2) at an altitude of some $\mathbf{2 8 0}$ masl; the formation is situated on the north-westemedge of the Thessalian plain, and thus lies between the western edge of the plain and the foothills of the eastern Pindus Mountains that constitute the natural border between Thessaly and Epirus (Kyparissi-Apostolika 2000). With the exception of some finds of Aurignacian 


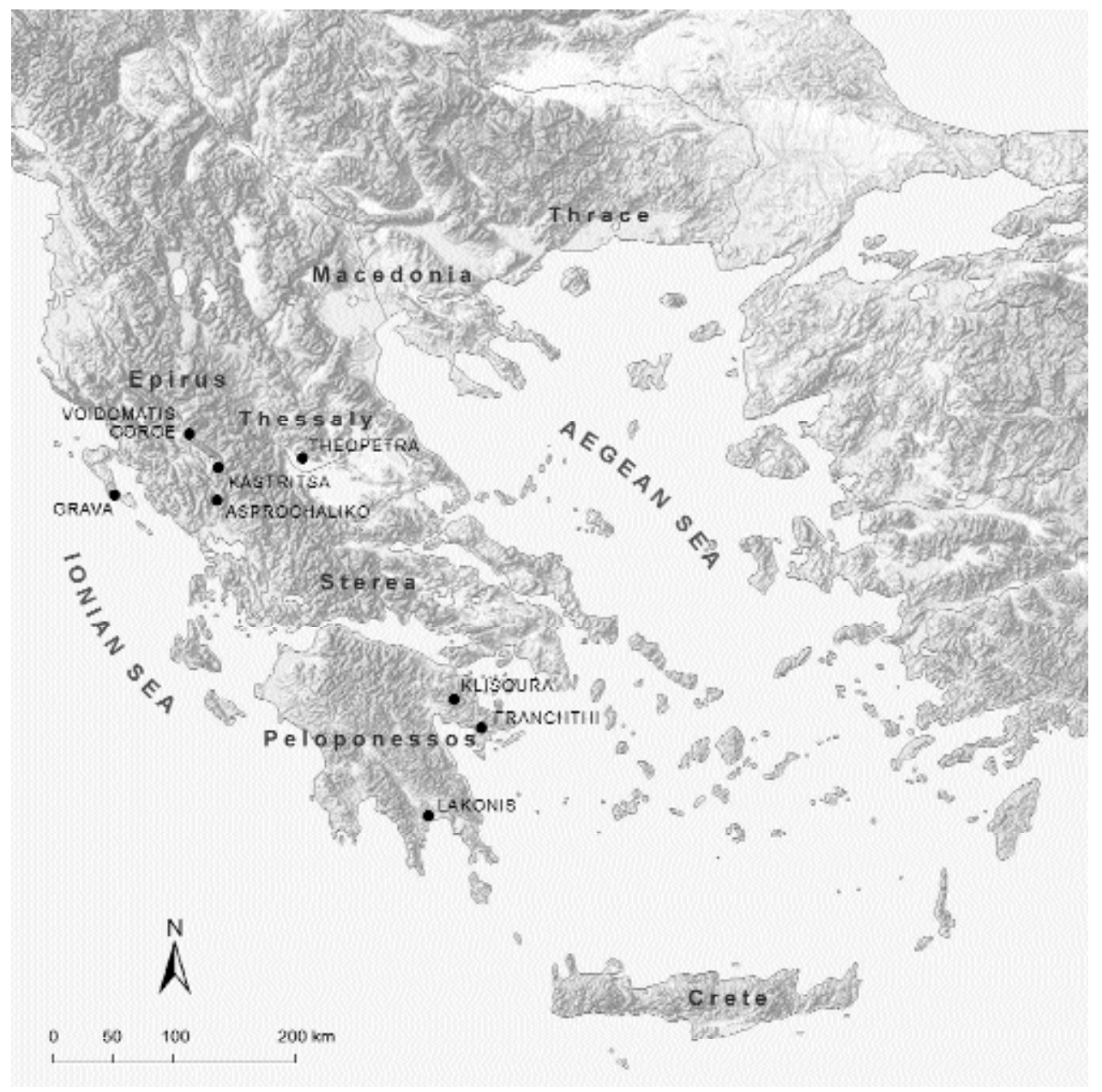

Figure 1 - Map of Greece indicating the location of the principal sites mentioned in the text.

Figure 1 - Carte de la Grèce montrant la localisation des principaux sites mentionnés dans le texte.

\begin{tabular}{|l|l|l|l|}
\hline SITE & \multicolumn{1}{|c|}{$\begin{array}{c}\text { STRATIGRAPHIC } \\
\text { UNIT }\end{array}$} & DATE B.P. & \multicolumn{1}{c|}{ SOURCE } \\
\hline ASPROCHALIKO & Layer 10 & $26,100 \pm 900$ & Bailey et al. 1983 \\
\hline KASTRITSA & Layer 24 (stratum 9) & $23,880 \pm 100$ & Galanidou \& Tzedakis 2001 \\
\hline & Layer 21 (stratum 9) & $21,800 \pm 470$ & Bailey et al. 1983 \\
& & $\begin{array}{c}23,200 \pm 480 \\
\text { Bailey et al. 1983 } \\
\text { Galanidou \& Tzedakis 2001 }\end{array}$ \\
\hline & Layer 20 (stratum 7) & $20,800 \pm 810$ & Bailey et al. 1983 \\
\hline & Layer 15 (stratum 5) & $19,900 \pm 370$ & Bailey et al. 1983 \\
& & $22,230 \pm 210$ & Galanidou \& Tzedakis 2001 \\
\hline & Layer 14 (stratum 5) & $20,590 \pm 70$ & Galanidou \& Tzedakis 2001 \\
\hline & Layer 13 (stratum 5) & $21,350 \pm 80$ & Galanidou \& Tzedakis 2001 \\
\hline & Layer 12 (stratum 5) & $20,000 \pm 80$ & Galanidou \& Tzedakis 2001 \\
\hline & Layer 7 (stratum 3) & $19,660 \pm 160$ & Galanidou \& Tzedakis 2001 \\
\hline & Layer 5 (stratum 1) & $19,360 \pm 160$ & Galanidou \& Tzedakis 2001 \\
\hline & Layer 2 (stratum 1) & $13,400 \pm 210$ & Bailey et al. 1983 \\
& & $15,930 \pm 130$ & Galanidou \& Tzedakis 2001 \\
\hline THEOPETRA & Unit/Episode II11 & $25,820 \pm 270$ & Karkanas 2001 \\
& & $25,625 \pm 500$ & Karkanas 2001 \\
\hline
\end{tabular}

Table 1 - Radiocarbon dates of the principal sites discussed in the text.

Tableau 1 - Datations ${ }^{14} \mathrm{C}$ des principaux sites évoqués dans le texte. 


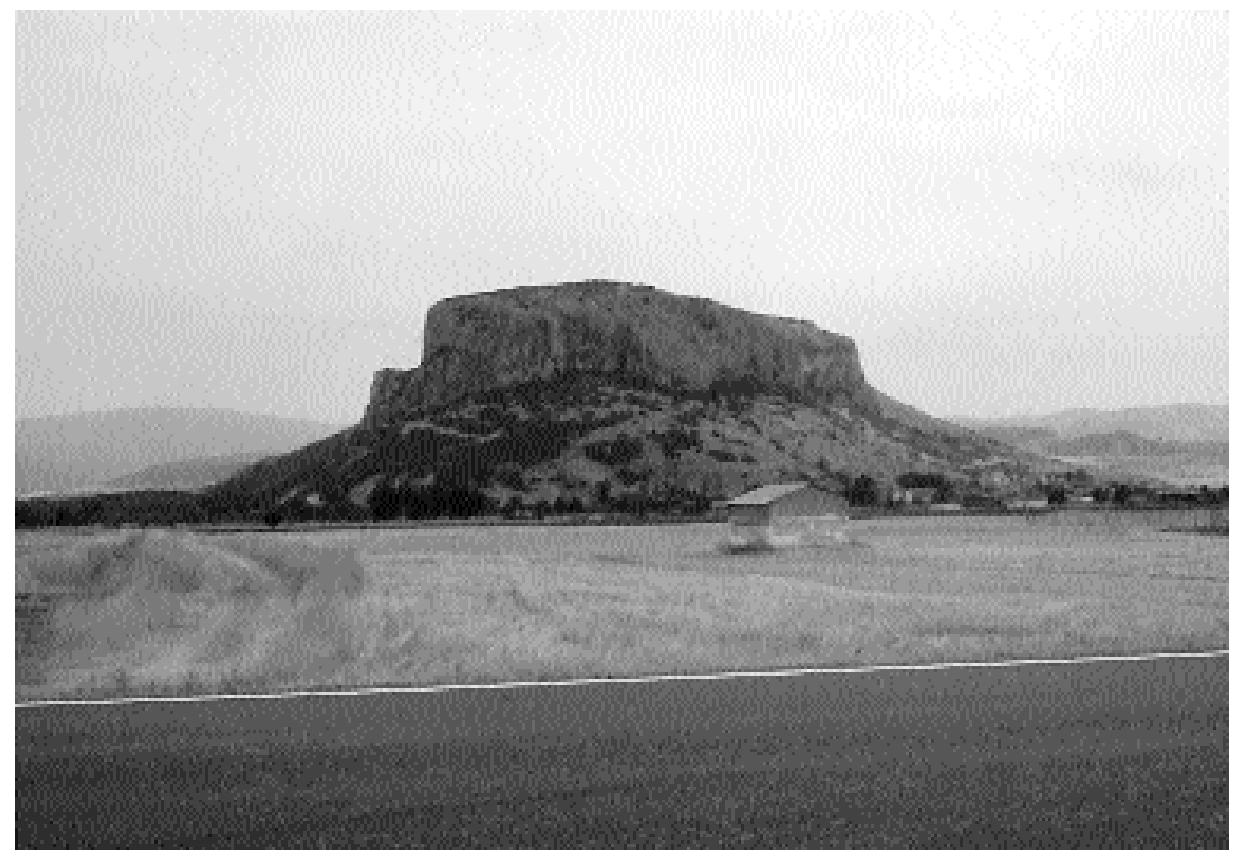

Figure 2 - General view of the Theopetra formation taken from the national road to Trikala (photo: $E$. Adam).

Figure 2 - Vue générale de la formation de Theopetra prise de la route nationale allant à Trekala (Photo E. Adam).

character, reported in the 1960's, Theopetra is so far the only site providing information on the Upper Palaeolithic and Mesolithic in Thessaly, all subsequent surveys having failed to identify Upper Palaeolithic and Mesolithic industries in the area (Runnels and van Andel 1999).

Excavations started in 1987 and have so far revealed a ca 6.5 metre - thick sequence with occupational events stretching from the Middle Palaeolithic to the Neolithic and recent times. Deposits (layers II10-II12) of Upper Palaeolithic date (see table 1), although represented over a large part of the excavated area, preserve very few securely classifiable artefacts (Adam 2000). The faunal material, too, (mostly herbivores of all sizes) appears to have undergone disturbances and intense destructive forces (Newton 1999). The sequence testifies to the existence of a series of cold phases, interspersed by periods of milder intervals (Karkanas 2001), such as the one represented by the extensive burning horizon dated at 25 kyr that is of interest here. The cold phases documented in the deposits may account for the non-availability of the site during a considerable part of the Upper Palaeolithic. Occupation at the site was resumed after about $14 \mathrm{kyr}$. The depositional process in the cave was further complicated by large bodies of invasive waters which, after the Late Glacial Maximum, removed an appreciable amount of the Upper Palaeolithic deposits, creating large channels and tunnels subsequently filled by later human activity (Karkanas 2001)

Artefact density at Theopetra is extremely low throughout the cultural sequence. The total of both Upper Palaeolithic and Mesolithic artefacts (from 15 excavation units analysed so far) amounts to the meagre number of 630 .

The depositional record of the cave and the sample itself suggest we are faced with the remains of Upper
Palaeolithic industry/ies mixed with artefacts from the preceding Middle Palaeolithic and the subsequent Mesolithic occupational phases. The sample from the area of the extensive burning episode of $25 \mathrm{kyr}$, in particular, is very poorly represented. Apart from a few backed bladelets, no diagnostic tool-types are present in this sample whose size is such that no meaningful comparisons can be made with industries of the same age (i.e. Asprochaliko and Franchthi phases II, III, Temnata Cave). No organic artefacts are reported from these layers either.

\section{2 - The Peloponnese}

Franchthi cave is situated in a limestone peninsula of the Hermionid region in eastern Peloponnese, very close to the present sea-shore. Excavations conducted between 1967 and 1976 by T. W. Jacobsen and his team revealed a sequence of discrete occupational phases ranging from the Middle Palaeolithic to the Neolithic. The excavated deposits at Franchthi represent nearly 30.000 years of prehistory, but over half of that time-span is in the form of hiatuses. Amongst these, and of relevance to the present paper, is an interval coinciding with the maximum glacier expansion in central and northern Eurasia; the site was occupied more or less continuously after 15 kyr (Farrand 2000).

During the first period of Upper Palaeolithic occupation (before the LGM) the use of the site was sporadic; the density of the archaeological material is reported to be extremely low (Perles 1999). The assemblages from "Lithic Phases" (Perles 1987) II (dated to ca $23 \mathrm{kyr}$ ) and III (undated) exhibit a preponderance of backed bladelets (reaching $80 \%$ of the tool inventory) and a very low representation of end-scrapers, notches and laterally retouched pieces (at 5 $\%$ each). Burins, bone tools and ornaments are not present at Franchthi (Perles 1999). 


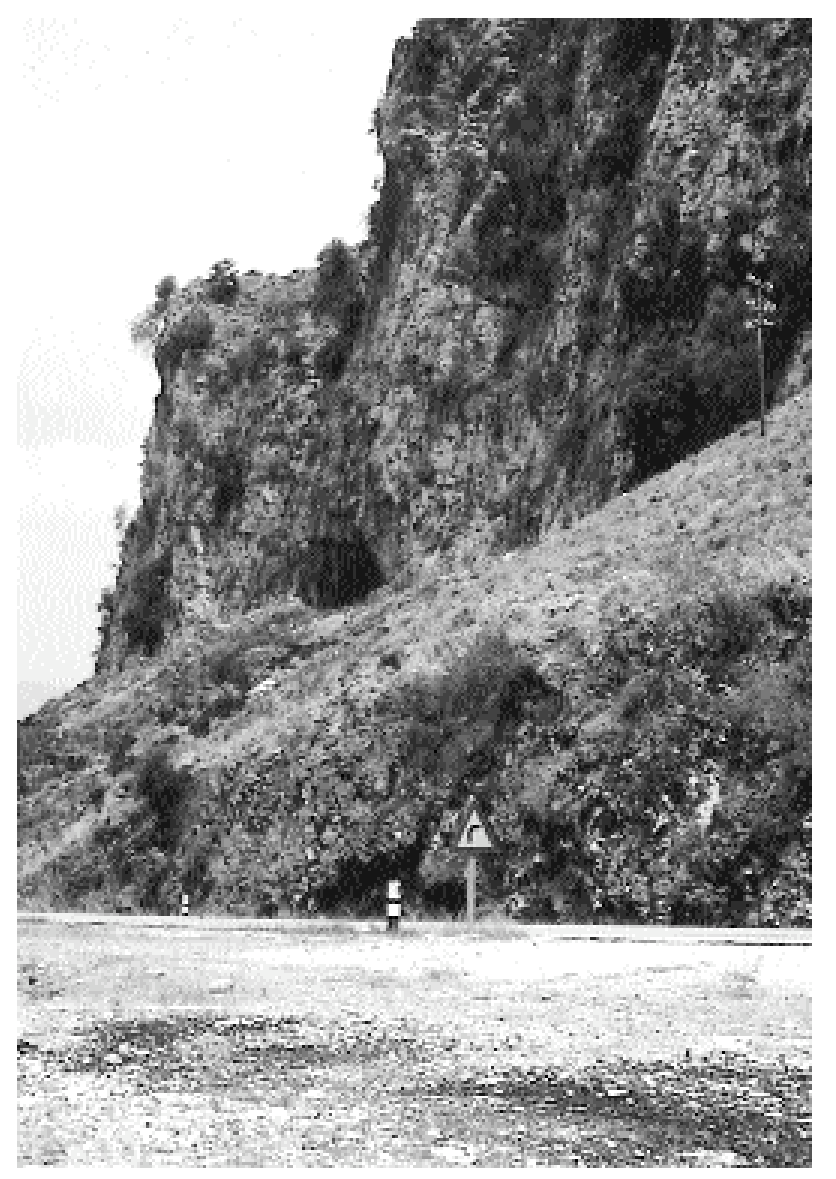

Figure 3 - General view of Asprochaliko taken from the main loannina-Arta road (photo: E. Adam).

Figure 3 - Vue générale d'Asprochaliko prise de la route loannina-Arta (Photo E. Adam).

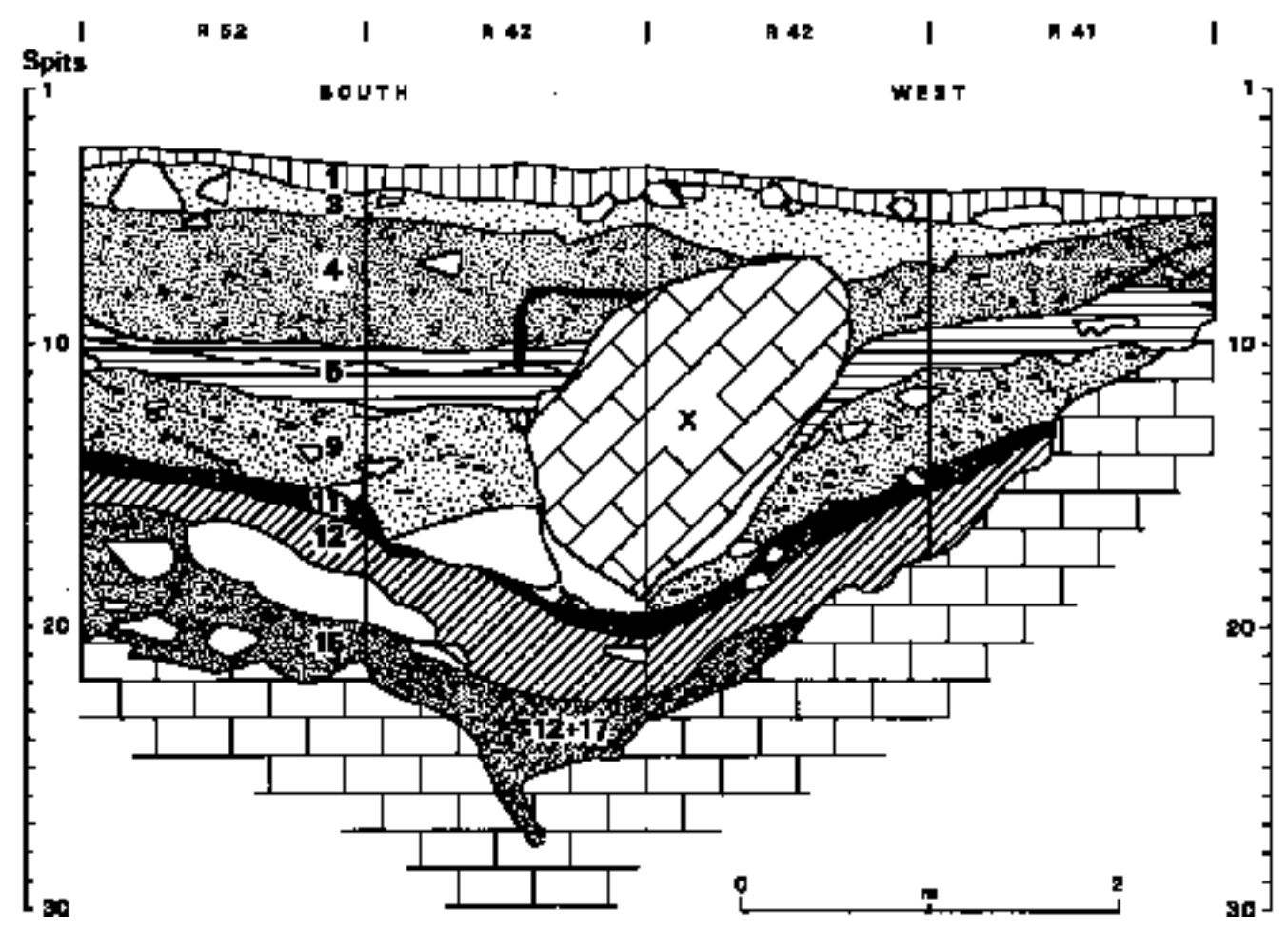

Figure 4 - Asprochaliko: west face of rectangles 41 and 42, and south face of rectangles 42 and 52 (after Bailey et al 1983, p.19).

Figure 4 - Asprochaliko: face ouest des rectangles 41 et 42 et face sud des rectangles 42 et 52 (d'après Bailey et al. 1983, p. 19). 
Two projects under way in eastern Peloponnese have not yet yielded evidence of Gravettian character. Klissoura gorge (some $60 \mathrm{~km}$ west of Franchthi, see fig. 1) has been the focus of attention for the past decade and has supplied evidence of Pleistocene and Holocene occupation at various rockshelter locations. It is interesting to note that a well defined Aurignacian sequence has been excavated in Cave 1, dated to the period between 24-20 kyr and followed by an Epigravettian phase dated to after $14 \mathrm{kyr}$ (Koumouzelis et al. 2004). On the other hand, Lakonis cave, on the eastern coast of the Mani peninsula (fig. 1), under excavation since 1999, yielded a long cultural sequence preserving Middle Palaeolithic and Initial Upper Palaeolithic occupation layers, radiometrically dated from ca 100 to 40 kyr (Panagopoulou et al. 2004), but no later material.

\section{3 - Northwest Greece}

The rockshelter of Asprochaliko (fig.3) is situated on a limestone formation on the right bank of the Louros river; located at an altitude of 200 masl it oversees the Louros valley. Excavations by the late E.S. Higgs and the late S.I. Dakaris between 1964 and 1966 established a sparingly dated sequence ranging from the Middle Palaeolithic to the Upper Palaeolithic (Higgs and Vita Finzi 1966). Only part of the site was excavated. The deposits are divided in two major units: those inside and those outside the rockshelter; the latter include both in situ and mixed deposits, and the cultural data retrieved from them cannot - with the exception of the Mousterian industry in layer $18-$ "...be treated with any confidence" (Bailey et al. 1983 p.24). Following that, we can only truly concentrate on the deposits inside the rockshelter (fig.4). This sequence runs through $5 \mathrm{~m}$ of deposits of stony clays and includes basal Mousterian (dated to ca $100 \mathrm{kyr}$ ) followed by upper Mousterian (originally named "micromousterian") and finally by Upper Palaeolithic industries.

A single date of $26 \mathrm{kyr}$ (layer 10) provides a minimum date for these industries. Attempts to obtain further radiocarbon dates from this part of the sequence were hindered by lack of collagen in the bones sampled for dating (Gowlett and Carter 1997). A sterile layer (layer 13) running throughout the excavated area and located between the Middle and the Upper Palaeolithic layers indicates a major hiatus in the occupation of the site. The faunal collections remain not fully studied but they are repored to be dominated by cervids and caprines (Bailey et al. 1983).

The Upper Palaeolithic industries from Asprochaliko (Adam 1989) are characterized by the lack of laminar blank production; indeed there are no blades or blade cores. Most cores are flake cores worked with limited preparation and maintenance and by frequent change of the flaking direction. The tool inventory (fig. 5) is dominated by bladelet tools (at ca $58 \%$ ) followed by end-scrapers (at ca 14.6 $\%$ ) and laterally retouched pieces (at ca $6 \%$ ), all made on flakes. No burins are present in the industries. The range of the backed bladelet types is limited and includes mostly unilaterally backed forms. Microburins are absent. No organic artefacts are as yet reported from Asprochaliko.
The Kastritsa ridge (fig.6) is a karst formation isolated in the loannina basin, some $10 \mathrm{~km}$ southeast of loannina and Lake Pamvotis. The homonymous site, at an altitude of ca 470 masl excavated by E.S. Higgs and his team during two excnciating field seasons in 1966 and 1967 (Higgs et al. 1967), lies at the western slope of the ridge (fig.7). The excavations reached a maximum depth of some 9 metres, revealing a sequence (fig. 8) of three units of terrestrial (strata 1,3,5), beach (strata 7,9) and lake (lower stratum 9) deposits (Bailey et al. 1983). The sequence is framed by sets of radiocarbon dates (by four original dates between ca 22 and $13 \mathrm{kyr}$ - Bailey et al 1983, and by one recent set of AMS dates between ca 24 and 15 kyr, Galanidou and Tzedakis 2001, see tabl. 1). The archaeological record from the first unit of deposits, that is the upper part of the sequence, testifies to more intensive use of the site compared to the lower ones. A number of recent analytical and interpretative studies (Elefanti 2003 ; Galanidou 1997 ; Kotjabopoulou 2001) focussing on particular aspects of the cultural data from Kastritsa have stressed its profile as a multi-purpose camp. The Kastritsa sequence offers both a window in diachronic techno-typological differentiation and a case of activity documentation, so far unparalleled by any other site on greek territory.
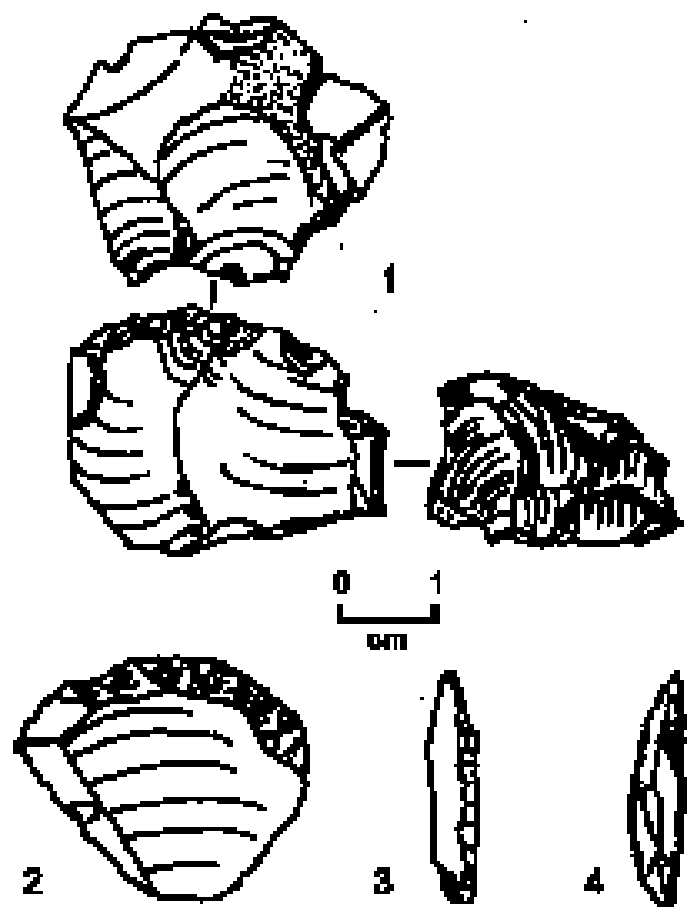

Figure 5 - Asprochaliko: selected artefacts from layers 4 and 10 (drawn by E. Adam).

Figure 5 - Asprochaliko : sélection d'objets provenant des couches 4 et 10 (dessins E. Adam). 


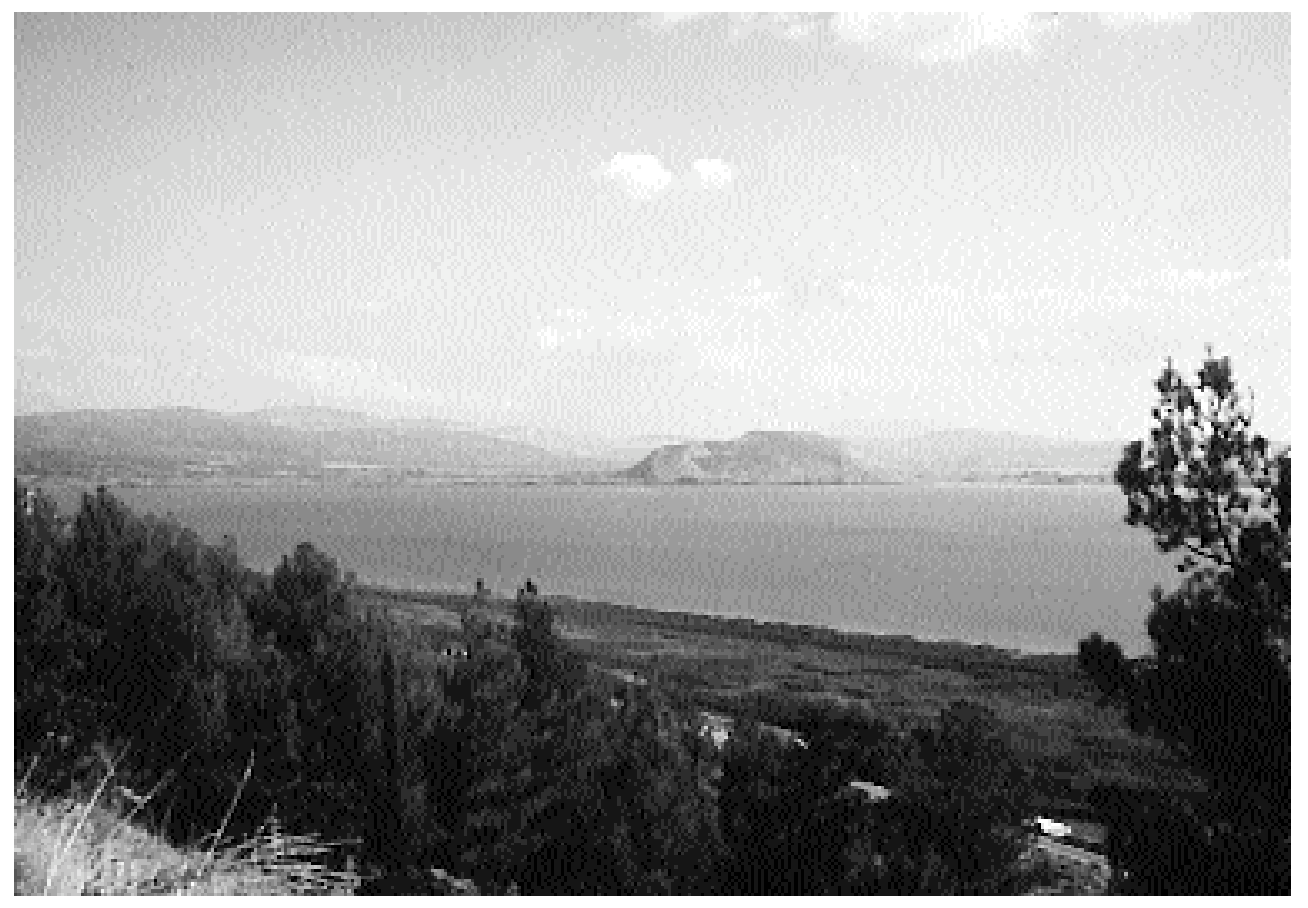

Figure 6 - General view of the Kastritsa formation taken from Mount Mitsikeli (photo: $E$. Adam).

Figure 6 - Vue générale de la formation de

Kastritsa prise du Mont Mitsikeli (Photo : E. Adam).

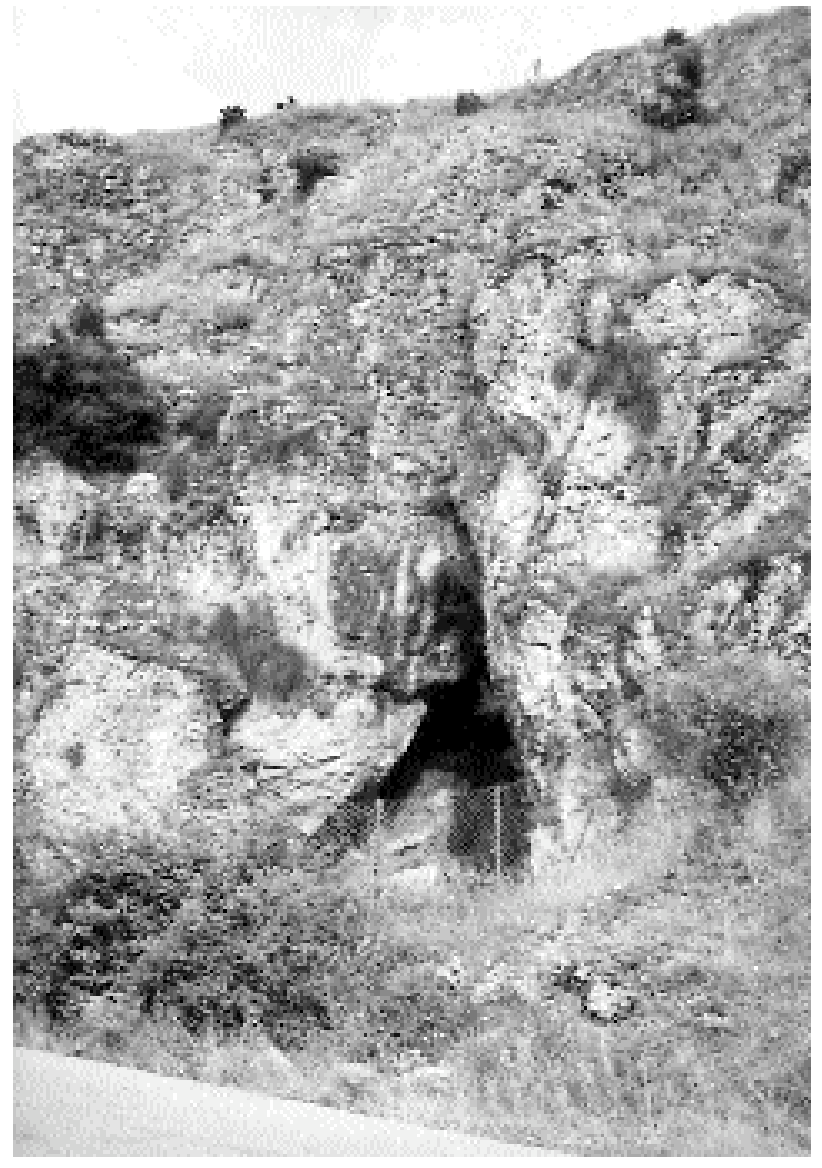

Figure 7 - General view of the Kastritsa cave taken from west, along the local district road (photo: E. Adam).

Figure 7 - Vue générale de la grotte de Kastritsa vue de l'ouest, de la route départementale (Photo E. Adam). 


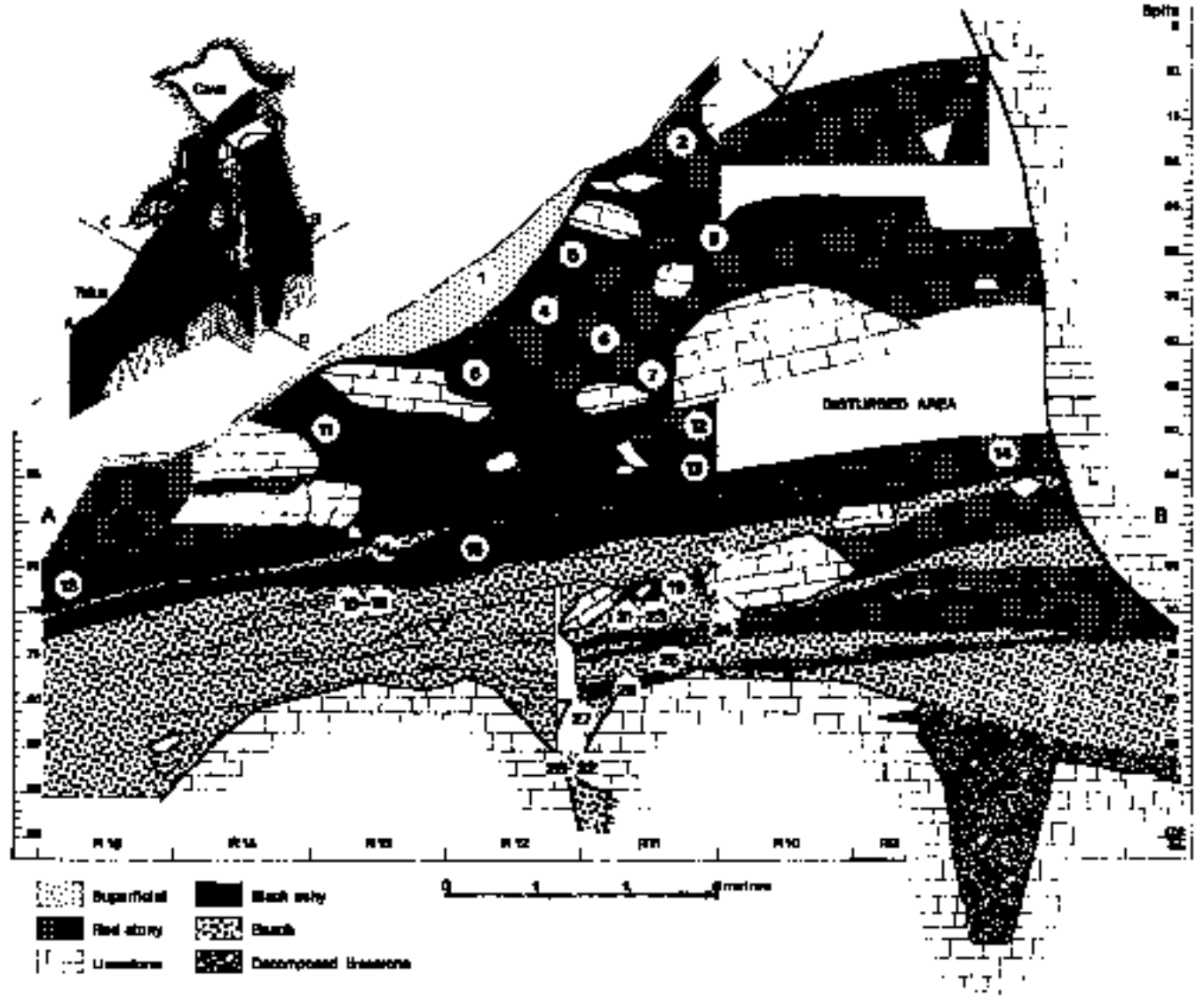

Figure 8 - Kastritsa: longitudinal section through Kastritsa deposits (after Bailey et al. 1983, p. 28).

Figure 8 - Kastritsa : coupe longitudinale (d'après Bailey et al. 1983, p. 28).

For the purposes of this paper we shall concentrate on strata 5 and 3 that fall well within the temporal range of the Gravettian; the topmost stratum 1 exhibits technological as well as chronological differentiation (Adam 1989, 1997, 1999).

The stone industries from Kastritsa are organised around two major parameters. One is the harvesting, for subsistence purposes, of populations of large ungulates (mostly red deer, and to a lesser degree aurochs and steppe ass as well as birds, Bailey et al 1983). The other parameter is the transformation of animal products (e.g. hide, antler, bone) into functional and decorative (symbolic, too) gear.

A general trend in the industries from strata 5 and 3 is - in contrast to Asprochaliko - the ability to produce long and straight blanks trough controlled and predetermined exploitation of the cores.

The industry from stratum 5 (fig.9) is, like in all strata, dominated by flakes; blades and bladelets are represen-

ted in roughly equal numbers. A type of flint, originating from the Voidomatis river area some $50 \mathrm{~km}$ northeast from Kastritsa is present in small quantities. Blade cores make their first appearance in the sequence. Shouldered pieces and points (by a single example each), and microgravettes appear for the first time in the industrial sequence $^{2}$. The number of piercers, dihedral burins and burins on breaks increases. End-scrapers are present in similar quantities to the burins; non- bladelet tools also include laterally retouched blades and totally or partially retouched pieces. Bladelet tools account for $51 \%$ of the tool group, and are represented mainly by unilaterally backed bladelets, plain (and secondly truncated, and bilaterally backed bladelets with opposed retouch and with inverse retouch on the ends).

The industry from stratum 3 (fig.10, 11) exhibits technological differentiation: the number of the cores increases and there is a shift in the method of their exploitation : tuming of the cores during flaking is replaced by the adoption of a

(2) A total of 20 shouldered points was part of a collection of 65 artefacts representative of the industries, compiled by the Higgs' team in 1966, and subsequently illustrated in P.P.S. 1967. The collection was exported to England, possibly for exhibition purposes, and was finally returned to the loannina Archaeological Museum by the Bailey team in 1985. Each artifact bears a unique code-number that allows it to be traced - through the meticulous Flint Bag Number lists - to its original provenance (rectangle, spit, layer), a task undertaken by the present author; according to these the shouldered points come from rectangles 2 and 3, stratum 1. Their presence had lead Higgs to postulate on the existence of a shouldered point horizon in the Kastritsa sequence (Higgs et al. 1967). The subsequent analysis of the industries showed that shouldered points occur from as early as stratum 5 with their number increasing progressively in strata 3 and 1. 

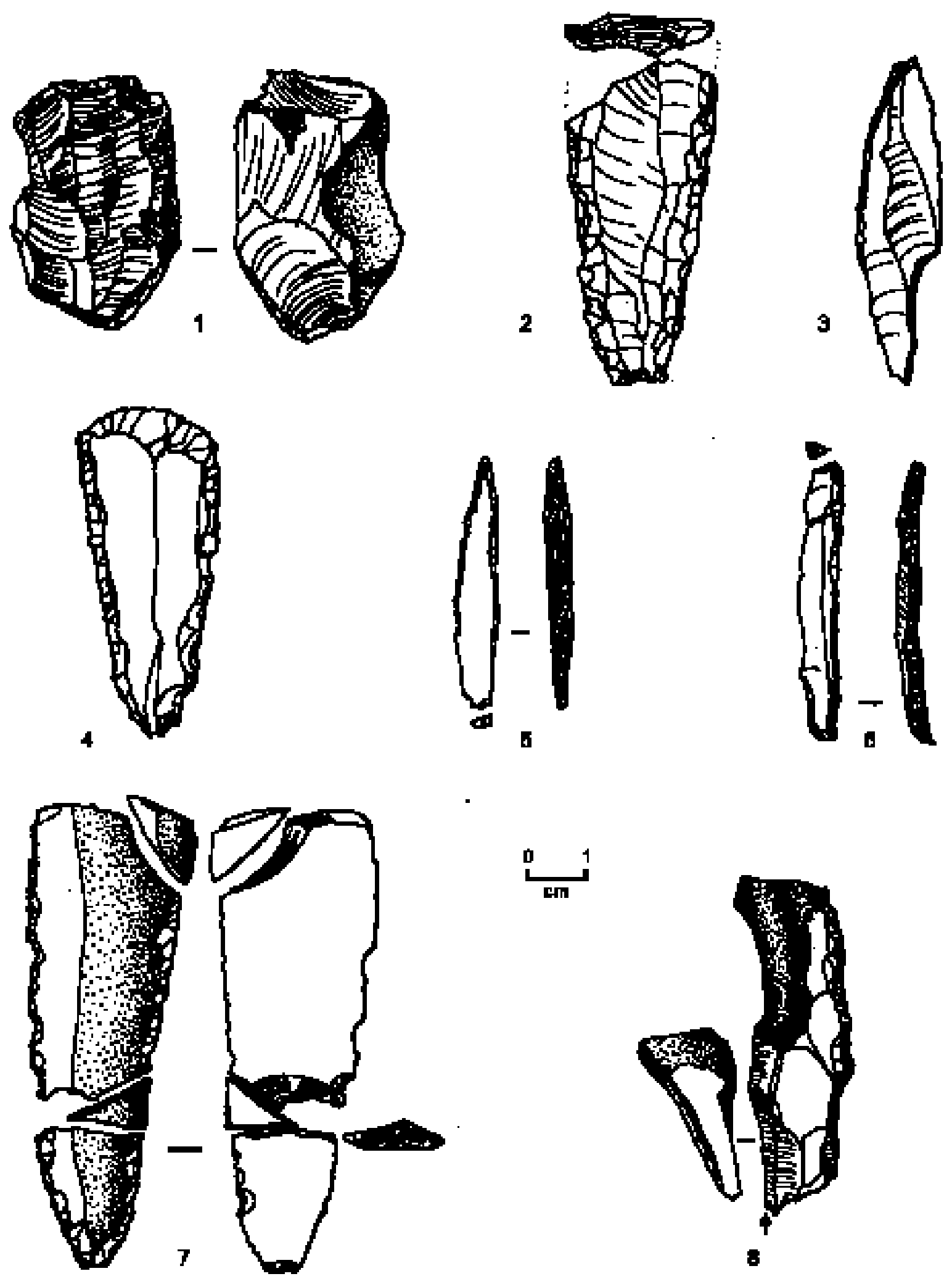

Figure 9 - Kastrisa: selected artefacts from stratum 5 (drawn by E. Adam).

Figure 9 - Kastritsa : sélection d'objets provenant de la couche 5 (dessins : E. Adam). 

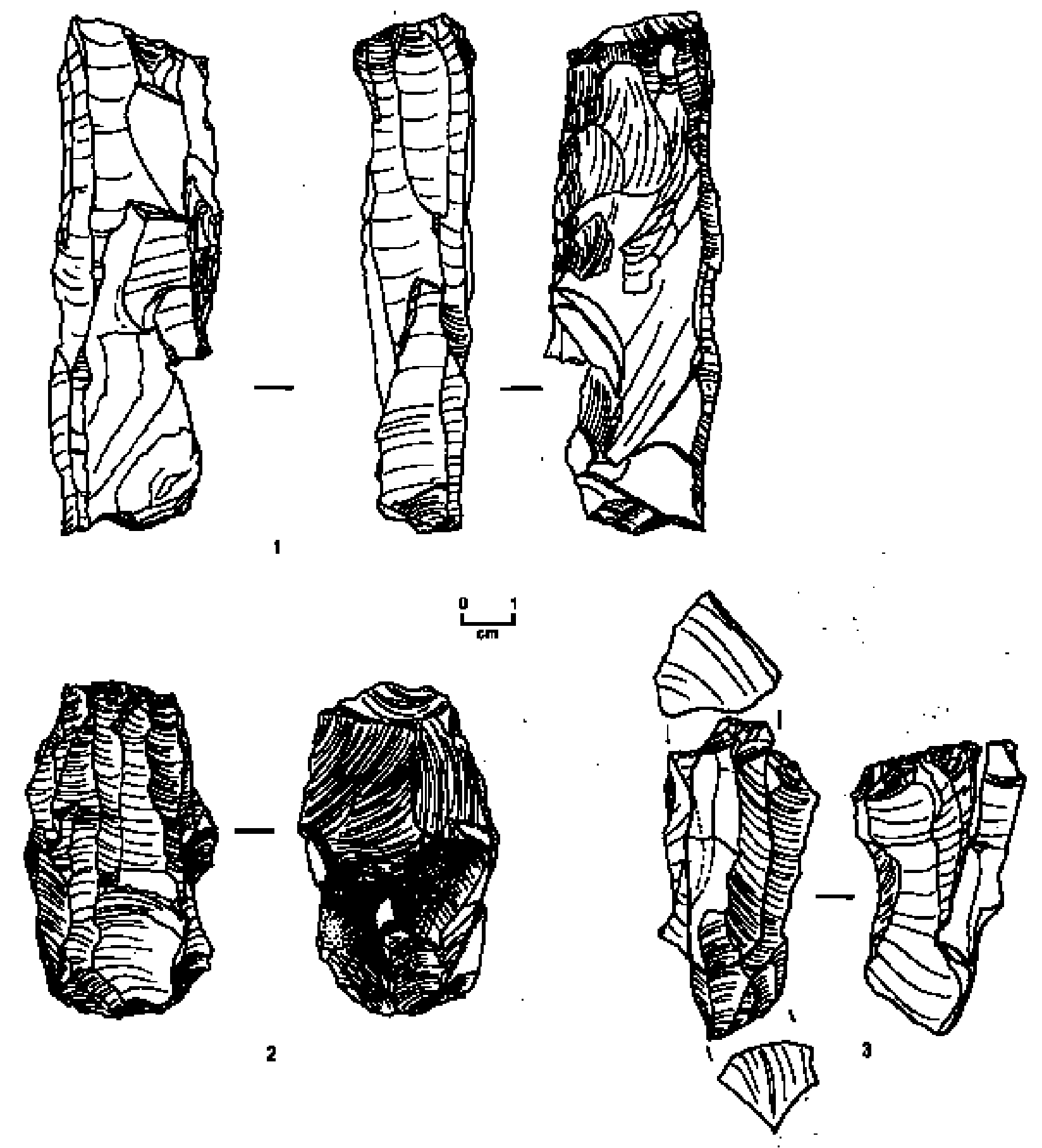

Figure 10 - Kastritsa: selected artefacts from stratum 3 (drawn by E. Adam).

Figure 10 - Kastritsa : sélection d'objets provenant de la couche 3 (dessins : E. Adam). 

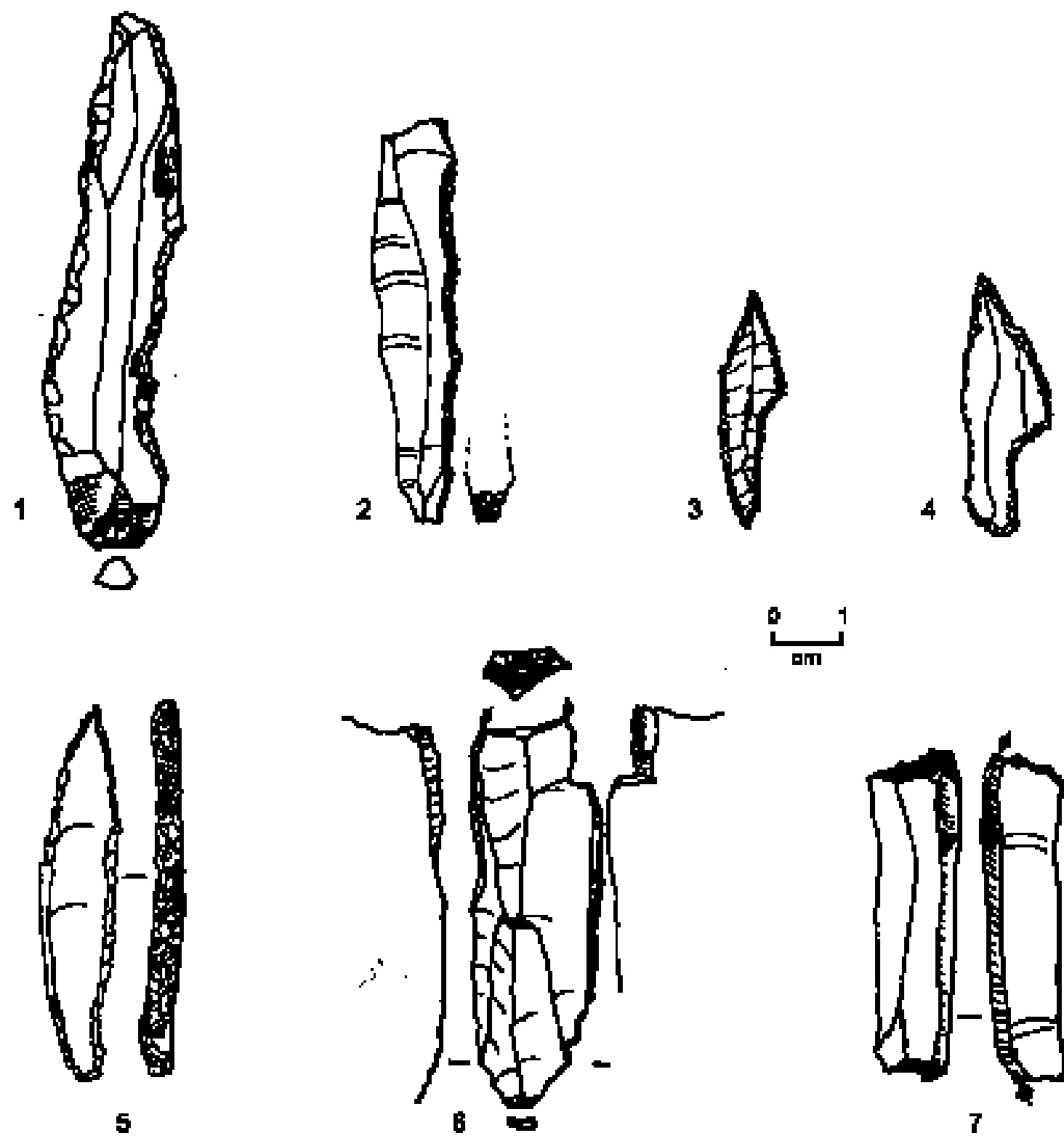

5

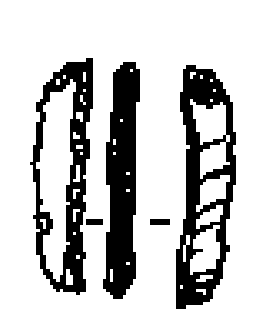

8

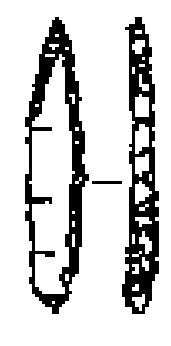

g
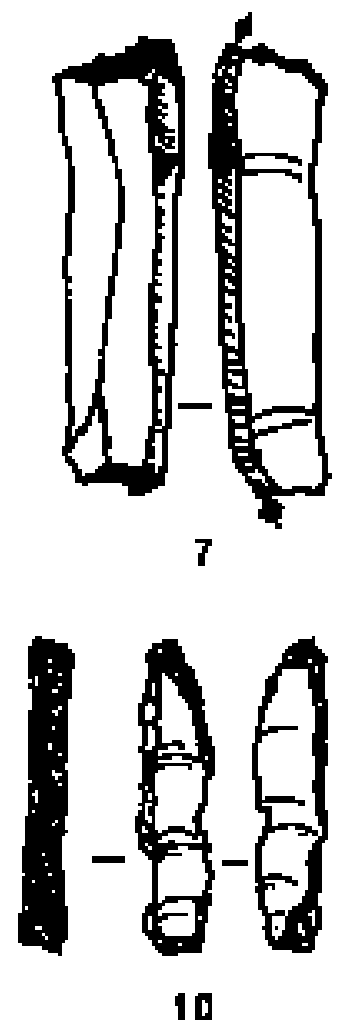

Figure 11 - Kastritsa: selected artefacts from stratum 3, continued (drawn by E. Adam).

Figure 11 - Kastritsa : sélection d'objets provenant de la couche 3 (suite) (dessins : E. Adam). 


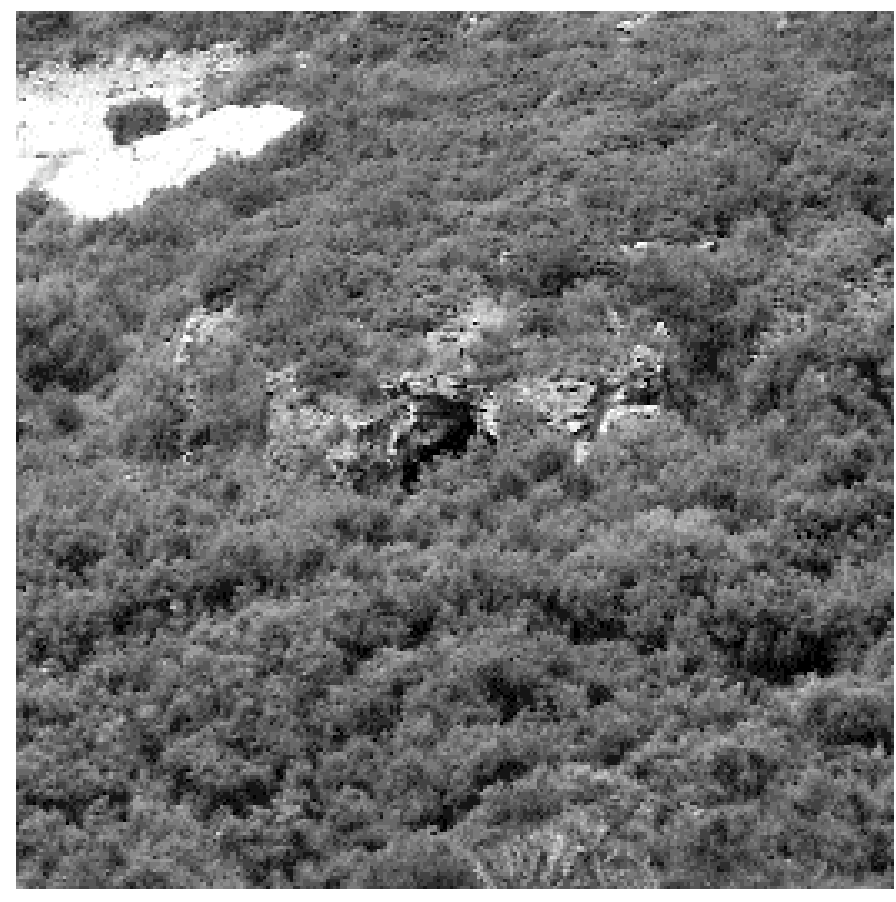

second platform at opposed axes to the first. The quantities of Voidomatis-type flint increase. Technological innovations include the intentional breakage of retouched and plain blades and the introduction of the microburin technique (albeit in small numbers; it is fully employed in stratum 1). Blade blanks are prefered to flakes for tool manufacture. Laterally retouched blades of various types are the commonest non-bladelet tool type. Burins outnumber end-scrapers, while multiple burins and micropiercers make their first appearance. The bladelet tool class (at $61 \%$ of the tool inventory) is dominated by backed bladelets (predominantly unilaterally backed plain, followed by backed bladelets with inversely retouched ends).

Another important feature of the Kastritsa assemblages is the presence of a considerable collection of organic art ifacts (Adam and Kotjabopoulou 1997), and of items of personal adornment and of symbolic value. The organic art ifacts $^{3}$, present in the sequence since at least stratum 5 (Adam 1999) were clearly complimentary to the stone tools. Most of them are made on antler, a material more solid and efficient than bone, and easily obtainable by the users of the site. The decorative items include 7 perforated deer canines (one with a decorative design), 2 serpentinite beads, 6 perforated dentalium sp. shells and 21 perforated shells (including 19 examples of Cyclope sp. shells) (Kotjabopoulou and Adam 2004).
Figure 12 - General view of the Grava shelter taken from the feet of Mount Mathias (photo: E.Adam).

Figure 12 - Vue générale de l'abri de Grava prise du pied du Mont Mathias (photo : E. Adam).
The variety of raw materials employed at the Kastritsa industries testifies to access over a wide area of exploitation. Judging by the presence of Voidomatis-type flint and of marine shells, materials were moved/provided for over considerable distances (between 50 and 100+ km). Although over-interpreting the data from a single site is an obvious risk, a picture can be sketched of a dynamic system of resource exploitation, through the exploration of and experimentation with materials and techniques.

The rockshelter of Grava (fig.12) is situated on the southern slopes of mount Ay. Mathias in south Corfu, at an altitude of c. 60 masl, and has a commanding view of the entire southern region of the island (Sordinas 1969). Trial excavations in 1966 explored the upper part of the brecciated scree deposits without reaching beyond the numerous rockfalls. No dates are available for Grava. The excavations produced an Upper Palaeolithic stone assemblage of some 2000 artefacts, supplemented by the fragment of an engraved bone, one perforated deer canine, one ochre-stained pebble and numerous pebbles, some with use traces, according to the excavator ${ }^{4}$. Birds abound in the fauna, while herbivores are dominated by bos primigenius followed by deer and capra species (Sordinas 1969).

The stone industries, according to the present stage of analysis, include two phases, one comparable to stratum 3 at

(3) With the publication of the organic implements from Kastritsa still pending (undertaken jointly by the author and Dr. Kotjabopoulou), the only comments to be made on these assemblages relate to their impressive number (well over 200 items) and their typological composition (mainly points with simple bases, few spatulas and awls and rare needles).

(4) The re-examination of the stone industries from Grava was initiated by the author in the late 1990's. The analysis is not yet completed; one major drawback is the inability to locate the original excavation records. In the absence of these, and based solely on the artefacts, I am inclined to suggest the presence of two techno-typological horizons, one comparable to that from stratum 3 and another comparable to that from stratum 1, both in the Kastritsa sequence. 


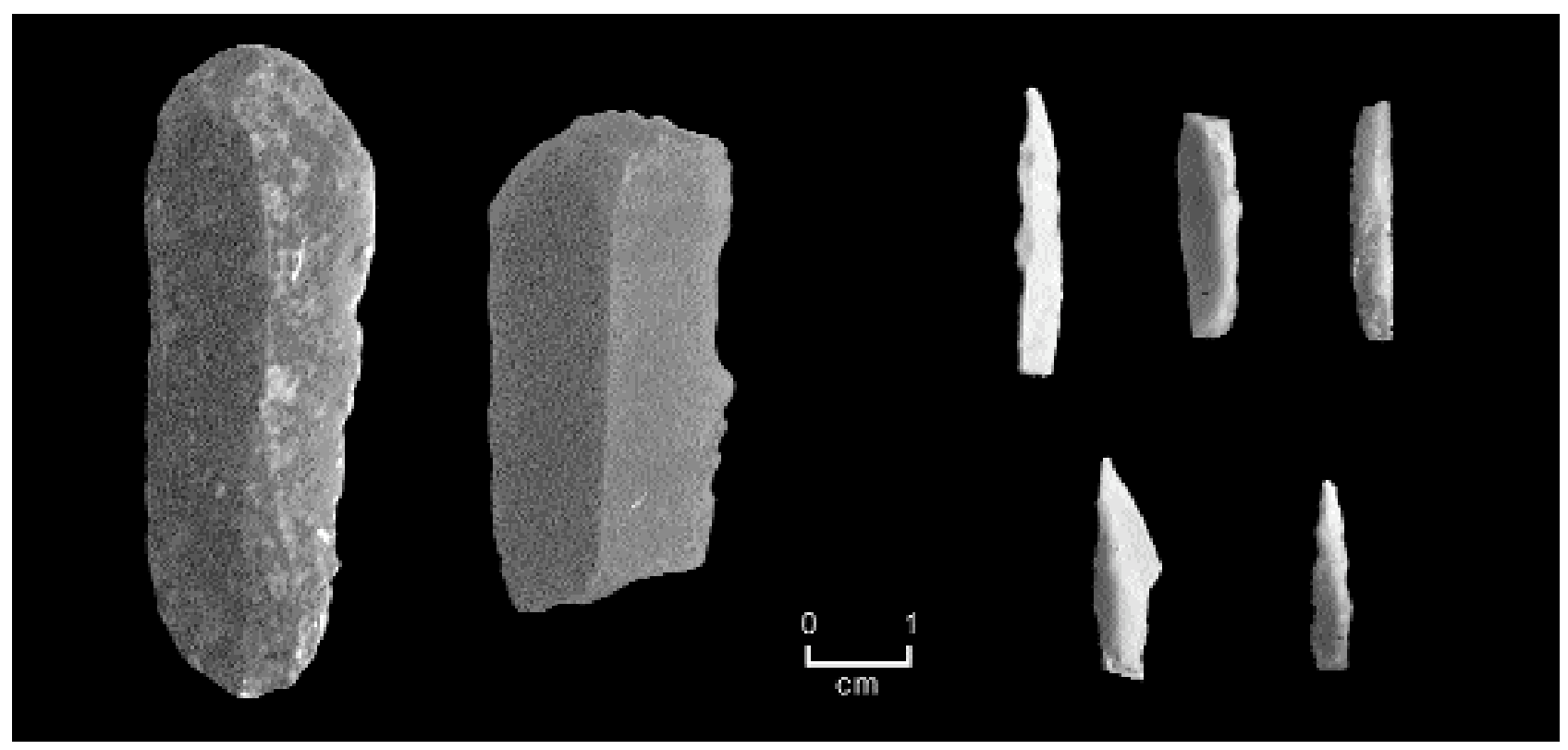

Figure 13 - Grava: selected artefacts (photo: E. Adam).

Figure 13 - Grava : sélection d'objets (photo : E. Adam).

Kastritsa, which is discussed in the present paper. The raw materials include a large variety of mostly fine-grained flints of various colours, similar to those recorded in the Epirus sites. The primary surfaces are cortical, while river-rolled pebbles are absent. Most cores present a single platform, with few opposed ones, and were exploited in order to produce blades and bladelets. Blades are abundant in the debitage class, outnumbering the bladelets. The tool inventory (fig. 13) includes backed bladelets of various types, endscrapers on retouched blades, burins and retouched blades, with a single occurrence of a shouldered point. Intentional breakage of blades is attested, same as at Kastritsa. The bladelet tool class is represented mostly by unilaterally backed bladelets, with few examples of backed types with retouched ends (occasionally with inverse retouch) and one microgravette. The composition of the bladelet tool class, too, resembles the one from Kastritsa.

\section{CONCLUSIONS}

The synthesis on the Gravettian in Greece attempted in this paper is in obvious need of refinement; unfortunately we are pestered with lack of a reliable body of comparable data. The greek record for the period between $30-20 \mathrm{kyr}$ is scanty and allows no general conclusions to be drawn.

Despite the small number of sites it appears that the region of northwest Greece provides the fullest documentation of Gravettian activity, with Kastritsa emerging as a key site.

Environmental conditions favorable for Palaeolithic settlement and a diversity of resources within a limited area, such as Epirus, provided refuge to human populations. The entire region of western Balkans seems to have acted during the LGM as a refuge area for populations seeking suitable settlement conditions (Kozlowski 1992). After that period the archaeological record of Greece offers more substantial evidence for occupation through the exploitation of various environmental niches (Bailey and Gamble 1990) made available after about $17 \mathrm{kyr}$ (e.g. the Voidomatis gorge sites, Theopetra, Franchthi)

Retuming to Epirus, it is of interest to mention that no Gravettian finds have so far been reported from Albania, a terrain geographically and environmentally closely related to Epirus. Indeed, recent research (surveys and excavations) in Albania has indicated the lack of finds of Gravettian character (Korkuti 2003), a fact interpreted as an indication that occupation in the area was interrupted between 26-13 kyr (Runnels et al. 2004).

The present paper merely tackled important issues related to the presence and the character of Gravettian cultural data in the greek Palaeolithic record. Future research will no doubt lead to the revision of the statements presented here.

\section{Acknowledgments}

D. Kalpakis prepared the map of sites included in the text and Y. Nakas and P. Behlis added the finishing touches to the illustrations of the artefacts. 


\section{BIBLIOGRAPHY}

ADAM E. 1989 - A technological and typological analysis of Upper Palaeolithic stone industries of Epirus, northwestem Greece. Oxford: BAR International Series 512, 267 p. ill.

ADAM E. 1997 - To know and to have: raw material availability and Upper Palaeolithic stone assemblage structure in Epirus. In: G.N.Bailey (Ed.), Klithi: Palaeolithic settlement and Quaternary landscapes in northwest Greece. Vol.2: Klithi in its local and regional setting. Cambridge: McDonald Institute Monographs, p. 481-496.

ADAM E. 1999 - The Upper Palaeolithic stone industries of Epirus in their regional setting. In: G. Bailey et al. (Ed.), The Palaeolithic of Greece and Adjacent Areas. Proceedings of the ICOPAG Conference, loannina (September 1994). London, British School at Athens Studies 3, p.137-147.

ADAM E. 2000 - The Upper Palaeolithic and Mesolithic stone assemblages of Theopetra cave and their contribution to an assessment of site use during the Late Pleistocene and Early Holocene (in greek). In: $\mathrm{N}$. Kyparissi-Apostolika (Ed.), Theopetra Cave. Twelve years of excavation and research 1987 - 1998. Proceedings of the International Conference, Trikala (6-7 november 1998). Athens, YPPO, p. 163-171.

ADAM E. and E. KOTJABOPOULOU 1997 - The organic artefacts from Klithi. In: G. Bailey (Ed.) Klithi: Palaeolithic settlement and Quatemary landscapes in northwest Græce. Vol.1: Excavation and intra-site analysis at Klithi. Cambridge: McDonald Institute Monographs, p. 245-259.

BAILEY G.N., P.L. CARTER, C.S. GAMBLE and H.P. HIGGS 1983 - Asprochaliko and Kastritsa : further investigations of Palaeolithic settlement and economy in Epirus (north-west Greece). Proceedings of the Prehistoric Society, 49, p.15-42, fig. tab. pl.

BAILEY G. and C. GAMBLE 1990 - The Balkans at 18000 BP: the view from Epirus. In O. Soffer and C. Gamble (Eds.) The World at 18000 BP, volume 1. High latitudes. London: Unwin Hyman, p. 148-167.

BAILEY G., E. ADAM, E. PANAGOPOULOU, C. PERLES and K. ZACHOS 1999 - The Palaeolithic of Greece and Adjacent Areas. Proceedings of the ICOPAG Conference, Ioannina (September 1994). London, British School at Athens Studies 3, 375 p. ill.

ELEFANTI P. 2003 - Hunter-gathere specialised subsistence strategies in Greece during the Upper Palaeolithic from the perspective of lithic technology. Oxford: BAR Interational Series 1130, 135 p. ill.

FARRAND A. 2000 - Depositional history of Franchthi Cave. Sediments, stratigraphy, and chronology. Bloomington and Indianapolis : Indiana University Press, 135 p. ill.
GALANIDOU N. 1997 - "Home is where the hearth is". The spatial organisation of the Upper Palaeolithic rockshelter occupations at Klithi and Kastritsa in northwest Greece. Oxford: BAR International Series 687, 153 p. ill.

GALANIDOU N. and P.C. TZEDAKIS 2001 - New ASM dates from Upper Palaeolithic Kastritsa. Proceedings of the Prehistoric Society, 67, p.271-278, fig. tab. pl.

GAMBLE C. 1999 - The Palaeolithic societies of Europe. Cambridge World Archaeology. Cambridge: Cambridge University Press, 505 p. ill.

GOWLETT J. and P. CARTER 1997 - The basal Mousterian of Asprochaliko rockshelter, Louros valley. In: G. Bailey (Ed.) Klithi: Palaeolithic settlement and Quaternary landscapes in northwest Greece. Vol.2: Klithi in its local and regional setting. Cambridge: McDonald Institute Monographs, p. 441-457.

HIGGS E.S. and C.VITA-FINZI, 1966 - The climate, environment and industries of Stone Age Greece, Part II. Proceedings of the Prehistoric Society, 32, p.1-29, fig. tab. pl.

HIGGS E.S., C. VITA-FINZI, D.R. HARRIS and A. FAGG 1967 - The climate, environment and industries of Stone Age Greece, Part III. Proceedings of the Prehistoric Society, 33, p. 1-29, fig. tab. pl.

KARKANAS P. 2001 - Site formation processes in Theopetra Cave: a record of climatic change during the Late Pleistocene and Early Holocene in Thessaly, Greece. Geoarchaeology, 16/4, p. 373-399, fig. tab. pl.

KORKUTI M. 2003 - Researches and studies of prehistory in Albania. In: D. Grammenos (Ed.), Recent research in the prehistory of the Balkans. Thessaloniki. Publications of the Archaeological Institute of northern Greece nr 3, p. 205-255.

KOTJABOPOULOU E. 2001 - Pattemed fragments and fragments of patterns: Upper Palaeolithic rockshelter faunas from Epirus northwestern Greece. Cambridge: University of Cambridge, 2001. 304 p., ill. Unpublished PhD Thesis.

KOTJABOPOULOU E. and E. ADAM 2004 - People, mobility and ornaments in Upper Palaeolithic Epirus, NW G reece. In: M. Otte (Ed.) La Spiritualité. Actes du Colloque de Liége (10-12 décembre 2003). Liége, Etudes et Recherches Archéologiques de l' Université de Liége, p. 37-53.

KOUMOUZELIS M., B. GINTER, J.K. KOZLOWSKI, B. KAZIOR and K. SOBCZYK 2004 - Cave 1 in Klisoura Gorge (Greece). Recherches Archéologiques de 19931998. Krakow, p. 206-220.

KOZLOWSKI J. 1992 - The Balkans in the Middle and Upper Palaeolithic : the gate to Europe or a cul-de sac ? Proceedings of the Prehistoric Society, 58, p. 1-29, fig. tab. pl. 
KYPARISSI -APOSTOLIKA N. 2000 - The excavations in Theopetra Cave 1987 - 1998 (in greek). In: N. Kyparissi-Apostolika (Ed.), Theopetra Cave. Twelve years of excavation and research 1987 - 1998. Proceedings of the International Conference, Trikala (6-7 november 1998). Athens, YPPO, p. 17-36.

NEWTON S. 1999 - Theopetra cave and the Palaeolithic Mesolithic transition in southern Europe. In: $\mathrm{E}$. Kotjabopoulou et al (Eds) Zooarchaeology in Greece. Recent advances. Athens, British School at Athens Studies 9, p.115-122.

OTTE M. 1981 - Le Gravettien en Europe Centrale. Disserationes Archaeologicae Gandenses vol. XX. Brugge: De Tempel, 505 p. ill.

PANAGOPOULOU E., P. KARKANAS, G. TSARTSIDOU, E. KOTJABOPOULOU, K. HARVATI and M. NTINOU 2004 Late Pleistocene archaeological and fossil human evidence from Lakonis cave, southern Greece. Joumal of Field Archaeology 29/3-4, p.3223-349, fig. tab. pl.

PERLES C. 1987 - Les industries lithiques taillées de Franchthi (Argolide, Grèce), tome I. Présentation générale et industries Paléolithiques. Excavations at Franchthi cave, Greece. Fascicle 3. Bloomington and Indianapolis: Indiana University Press.
PERLES C. 1999 - Long-term perspectives on the occupation of the Franchthi cave: continuity and discontinuity. In G.N. Bailey et al. (Eds.) The Palaeolithic of Greece and adjacent areas. Proceedings of the ICOPAG Conference, loannina (September 1994). Athens, British School at Athens Studies 3, p. 311-318.

RUNNELS C. and T. J. van ANDEL 1999 - The Palaeolithic in Larissa, Thessaly. In G.N. Bailey et al. (Eds.) The Palaeolithic of Greece and adjacent areas. Proceedings of the ICOPAG Conference, loannina (September 1994). Athens, British School at Athens Studies 3, p. 214-220.

RUNNELS C., M. KORKUTI, M.L. GALATY, M.E. TIMPSON, J.C. WHITTAKER, S.R. STOCKER, J.L. DAVIS, L. BEJKO and S. MUCAJ 2004 - The Palaeolithic and Mesolithic of Albania: survey and excavation at the site of Kryegjata B (Fier district). Journal of Mediterranean Archaeology 17/1, p.3-29, fig. tab. pl.

SORDINAS A. 1969 - Investigations in the prehistory of Corfu during 1964-66. Balkan Studies, 10/2, p.393-424, fig. tab. pl.

VALOCH K. 1996 - L'origine du Gravettien de I' Europe Centrale. In: A. Palma di Cesnola (Ed.), The origin of the Gravettian. Colloquium XII, XIII International Congress of UISPP, Forli (8-24 september 1996). Forli, ABACO volume 6, p. 203-207. 